\title{
PENGGUNAAN MEDIA PUZZLE KONSTRUKSI TERHADAP HASIL BELAJAR KOGNITIF SISWA SDN KEMANGSEN II KRIAN
}

\author{
Eka Wahyu Hidayati \\ Sekolah Tinggi Agama Islam Daruttaqwa (STAIDA), Gresik \\ e-mail: eccha.ayu91@gmail.com
}

\begin{abstract}
Learning is a complex process and it can occur due to the interaction between man and his environment, his teachers, his friends and even the most important and the man who became the first school of every human being is mimic their parents. A puzzle game is entertaining game and can be enjoyed by children and adults by concentrating and using his thought power optimally in a way to understand and grasp the dimensions of the puzzle in order to complete this game. This study uses a quantitative research design which is the type of research that used is quantitative experimental approaches with One Group Pretest-Postest Design, which is a type of research that provides design pretest before and after being treated. Of the two questions researchers can be found the following reply. The First, there is influence of using puzzle media construction of the cognitive achievement of students in Civics subject which to understand the freedom to organize the fifth grade at SDN Kemangsen II, it's proved by $t$ table for a 5\% error with $\mathrm{db}=$ $N-1=27$ was 2.05. Because of ( $t$ count $>t$ table) is $20.44<$ 2.060. The Second, the amount of influence the media construction puzzle of cognitive achievement students in the subjects of Civics in understands the freedom to organize the fifth grade at SDN Kemangsen II in the academic year 2014/2015 amounted to $40.7 \%$.
\end{abstract}

Keywords: Puzzle, Cognitive, Civic Education.

\section{Pendahuluan}

Pendidikan merupakan sarana utama dalam upaya meningkatkan kualitas sumber daya manusia. Tanpa pendidikan 
akan sulit diperoleh hasil dari kualitas sumber daya manusia yang maksimal. ${ }^{1}$ Dalam Undang-undang Republik Indonesia nomor 20 tahun 2003 tentang Sistem Pendidikan Nasional dan penjelasannya pasal 1 menyatakan bahwa, pendidikan adalah usaha sadar dan terencana untuk mewujudkan suasana belajar dan proses pembelajaran agar peserta didik secara aktif mengembangkan potensi dirinya untuk memiliki kekuatan spiritual keagamaan, pengendalian diri, kepribadian, kecerdasan, akhlak mulia, serta keterampilan yang diperlukan dirinya, masyarakat bangsa, dan negara. ${ }^{2}$

Belajar adalah suatu proses yang kompleks yang terjadi pada diri setiap orang sepanjang hidupnya. Proses belajar itu dapat terjadi karena adanya interaksi antara seseorang dengan lingkungannya. Oleh karena itu, belajar dapat terjadi kapan saja dan di mana saja kita berada. Salah satu tandanya seseorang telah belajar adalah adanya perubahan tingkah laku pada dirinya yang mungkin disebabkan oleh terjadinya perubahan pada tingkat pengetahuan, keterampilan, atau sikapnya. ${ }^{3}$

Hasil belajar adalah perubahan tingkah laku sebagai hasil belajar dalam pengertian yang lebih luas mencakup bidang kognitif, afektif, dan psikomotorik. Hasil belajar juga merupakan suatu interaksi tindak belajar dan tindak mengajar.

\footnotetext{
1 Hasbullah, Dasar-dasar Ilmu Pendidikan (Jakarta: PT. Raja Grafindo Persada, 2006), 144.

${ }^{2}$ Undang-undang Republik Indonesia Nomor 20 Tahun 2003 tentang Sistem Pendidikan Nasional (Bandung: Fokus Media, 2009), 2.

${ }^{3}$ Azhar Arsyad,.Media Pembelajaran (Jakarta: Rajawali Pers, 2011), 1.
} 
Dari sisi guru, tindak mengajar diakhiri dengan proses evaluasi hasil belajar. Sedangkan dari sisi siswa hasil belajar merupakan berakhirnya pengajaran dari puncak proses belajar. Hasil belajar kognitif adalah hasil belajar intelektual yang terdiri dari enam aspek, antara lain: pengetahuan dan ingatan, pemahaman, aplikasi, analisis, sintesis, evaluasi. ${ }^{4}$

Pada kenyataannya hasil belajar kognitif siswa pada mata pelajaran PKn kelas $\mathrm{V}$ pokok bahasan memahami kebebasan berorganisasi di SDN Kemangsen II masih rendah. Hal ini dibuktikan dengan hasil wawancara dengan guru kelas $\mathrm{V}$ pada saat guru menyampaikan materi pelajaran, bahwa siswa masih kurang mampu dalam memahami, memberikan contoh, dan menjelaskan konsep dari materi yang diajarkan oleh guru. Sehingga, hal ini berpengaruh pada aspek kognitif siswa yang kurang optimal.

Salah satu cara untuk meningkatkan hasil belajar siswa adalah memberikan variasi dalam mengajar. Variasi dalam mengajar dapat dilakukan dengan memberikan variasi media pembelajaran pada siswa. Ada beberapa variasi media yang dapat dipakai untuk menunjang kegiatan belajar mengajar. Misalnya media audio, media visual, dan media audio visual. berdasarkan salah satu karakteristik siswa SD yang suka bermain ada beberapa media yang cocok digunakan dalam pembelajaran, yaitu permainan kartu, domino hitung, scrable,

\footnotetext{
${ }^{4}$ Tim pengembang MKDP, Kurikulum \& Pembelajaran (Jakarta:Rajawali Pers, 2013), 140
} 
puzzle, dan lain-lain. Media yang sesuai digunakan pada pembelajaran PKn kelas V khususnya pada pokok bahasan memahami kebebasan berorganisasi menurut peneliti adalah dengan menggunakan media puzzle konstruksi.

Puzzle adalah permainan teka-teki atau bongkar pasang yang menghibur dan dapat dinikmati oleh anak-anak maupun orang dewasa. Namun permainan puzzle memiliki urgensi yang besar dalam mengembangkan imajinasi dan pemikiran yang inovatif di dalam diri manusia. Sebab, manusia dipaksa untuk berkonsentrasi dan menggunakan daya pikirnya secara maksimal agar dapat menyelesaikannya. Bahkan manusia membutuhkan kadar tertentu dari imajinasi supaya dapat memahami dan menangkap dimensi-dimensi puzzle (teka-teki), karena puzzle (teka-teki) tidak lain adalah pertanyaan tidak biasa yang membutuhkan pemikiran yang tidak lazim dan tidak langsung agar bisa dijawab dengan benar. ${ }^{5}$

Puzzle konstruksi merupakan kumpulan potonganpotongan yang terpisah, yang dapat digabungkan kembali menjadi beberapa model. Mainan rakitan yang paling umum adalah blok-blok kayu sederhana berwarna-warni. Mainan rakitan ini sesuai untuk anak yang suka bekerja dengan tangan, suka memecahkan puzzle, dan suka berimajinasi. ${ }^{6}$

\footnotetext{
5 Abdullah Muhammad Abdul Mu'thi, Be a Genius Teacher. terj. Najib Junaidi (Surabaya: Pustaka eLBA. 2008), 38.

Hani Epeni, Pengertian Media Puzzle, dalam http://kuliah.itb.ac.id/course/info.php?id=435.
} 
Media pembelajaran puzzle merupakan media pembelajaran bentuk permainan yang menantang daya kreatifitas dan ingatan siswa. Permainan ini lebih berkesan saat pembelajaran dikarenakan munculnya motivasi siswa untuk senantiasa mencoba memecahkan masalah, namun tetap menyenangkan sebab bisa diulang-ulang. Tantangan dalam permainan ini akan selalu memberikan efek ketagihan untuk selalu mencoba, mencoba dan terus mencoba hingga berhasil. Bermain dapat memberikan kesempatan kepada anak untuk berpikir dan bertindak imajinatif serta penuh daya khayal yang erat hubungannya dengan perkembangan kreatifitas peserta didik kita.

\section{Konsep Media}

Kata media berasal dari bahasa Latin medius yang secara harfiah berarti 'tengah', 'perantara' atau 'pengantar'. Dalam bahasa Arab, media adalah perantara atau pengantar pesan dari pengirim kepada penerima pesan. ${ }^{7}$ Media pembelajaran merupakan alat bantu yang berfungsi untuk menjelaskan sebagian dari keseluruhan program pembelajaran yang dianggap belum jelas. Materi pembelajaran akan lebih jelas jika digunakan media pembelajaran. Maka media pembelajaran tidak untuk menjelaskan keseluruhan materi pelajaran, tetapi sebagian yang belum jelas saja. Ini sesuai dengan fungsi media yaitu

\footnotetext{
${ }^{7}$ Arief, S. Sadiman, dkk, Media Pendidikan Pengertian, Pengembangan dan Pemanfaatannya (Jakarta:Raja Grafindo Persada, 2007), 6.
} 
sebagai penjelas pesan. $^{8}$ Untuk itu guru harus memiliki pengetahuan yang cukup tentang media pengajaran, yang meliputi:

a. Media sebagai alat komunikasi guna lebih mengefektifkan proses belajar mengajar;

b. Fungsi media dalam rangka mencapai tujuan pendidikan;

c. Seluk-beluk proses belajar;

d. Hubungan antara metode mengajar dan media pendidikan;

e. Nilai atau manfaat media pendidikan dalam pengajaran;

f. Pemilihan dan penggunaan media pendidikan;

g. Berbagai jenis alat dan teknik media pendidikan;

h. Media pendidikan dalam setiap mata pelajaran;

i. Usaha inovasi dalam media pendidikan. ${ }^{9}$

Dari pendapat para ahli di atas dapat disimpulkan bahwa media pembelajaran adalah suatu alat bantu komunikasi yang bisa digunakan untuk menunjang pembelajaran, memudahkan siswa dalam mempercepat pemahaman siswa pada saat guru menerangkan atau menjelaskan mata pelajarannya dan merupakan bagian yang tidak terpisahkan dari proses belajar mengajar demi tercapainya tujuan pendidikan pada umumnya dan tujuan pembelajaran di sekolah pada khususnya.

Dalam suatu proses belajar mengajar, dua unsur yang sangat penting adalah metode mengajar dan media pengajaran.

8 Musfiqon, Aplikasi Media Pembelajaran (Sidoarjo: Muhammadiyah University Press, 2008), 27.

${ }^{9}$ Arsyad, Media Pengajaran, 2. 
Kedua aspek ini saling berkaitan. Pemilihan salah satu metode mengajar tertentu akan mempengaruhi jenis media pengajaran yang sesuai, meskipun masih ada berbagai aspek lain yang harus diperhatikan dalam memilih media, antara lain tujuan pengajaran, jenis tugas dan respon yang diharapkan siswa kuasai setelah pengajaran berlangsung, dan konteks pembelajaran termasuk karakteristik siswa. Meskipun demikian, dapat dikatakan bahwa salah satu fungsi utama media pengajaran adalah sebagai alat bantu mengajar yang turut mempengaruhi iklim, kondisi, dan lingkungan belajar yang ditata dan diciptakan oleh guru. Pemakaian media pengajaran dalam proses belajar mengajar dapat membangkitkan keinginan dan minat yang baru, membangkitkan motivasi dan rangsangan kegiatan belajar, dan bahkan membawa pengaruh-pengaruh psikologis terhadap siswa. ${ }^{10}$ Manfaat praktis media pembelajaran di dalam proses belajar mengajar sebagai berikut:

a. Media pembelajaran dapat memperjelas penyajian pesan dan informasi sehingga dapat memperlancar dan meningkatkan proses dan hasil belajar.

b. Media pembelajaran dapat meningkatkan dan mengarahkan perhatian anak sehingga dapat menimbulkan motivasi belajar, interaksi yang lebih langsung antara siswa dan lingkungannya, dan kemungkinan siswa untuk belajar sendiri-sendiri sesuai dengan kemampuan dan minatnya.

${ }^{10}$ Arsyad, Media Pembelajaran, 15. 
c. Media pembelajaran dapat mengatasi keterbatasan indera, ruang dan waktu.

d. Media pembelajaran dapat memberikan kesamaan pengalaman kepada siswa tentang peristiwa-peristiwa di lingkungan mereka, serta memungkinkan terjadinya interaksi langsung dengan guru, masyarakat, dan lingkungannya misalnya melalui karya wisata. Kunjungan-kunjungan ke museum atau kebun binatang. ${ }^{11}$

Dalam proses pembelajaran diperlukan media pembelajaran yang tepat, sehingga proses pembelajaran dapat berjalan dengan baik dan mencapai tujuan pembelajaran yang diinginkan. Berikut ini klasifikasi media pembelajaran menurut Sadiman:

a. Media auditif, yaitu media pembelajaran yang hanya mengandalkan kemampuan suara saja, seperti radio, tape recorder, piringan audio. Media pembelajaran ini cocok untuk orang yang tuli atau mempunyai kelainan dalam pendengaran.

b. Media visual, yaitu media pengajaran yang hanya mengandalkan gambar diam, seperti film strip (film rangkai), foto, gambar, lukisan, dan cetakan.

c. Media audio visual, yaitu media yang mempunyai unsur antara suara dan gambar. Jenis media seperti ini mempunyai kemampuan yang lebih baik karena meliputi

${ }^{11}$ Arsyad, Media Pembelajaran, 26-27. 
suara dan gambar seperti film bingkai, ada suaranya dan adapula gambar yang ditampilkannya. ${ }^{12}$

Selain tiga klasifikasi di atas, ada klasifikasi lain tentang media pembelajaran yang dikelompokkan menjadi empat jenis, yaitu:

a. Media visual, yaitu media yang digunakan hanya mengandalkan indera penglihatan semata-mata dari peserta didik. Dengan media ini, pengalaman belajar yang dialami peserta didik sangat tergantung pada kemampuan penglihatannya. Beberapa media visual antara lain: 1) media cetak seperti buku, modul, jurnal, peta, gambar dan poster; 2) model dan prototype seperti globe, bumi; 3) media realitas alam sekitar dan sebagainya.

b. Media audio, yaitu jenis media yang digunakan dalam proses pembelajaran dengan hanya melibatkan indera pendengaran peserta didik. Contoh media audio yang umum digunakan adalah tipe recorder, radio, dan $\mathrm{CD}$ player.

c. Media audio visual, yaitu jenis media yang digunakan dalam kegiatan pembelajaran dengan melibatkan pendengaran dan penglihatan sekaligus dalam satu proses atau kegiatan. Contoh media ini adalah film, video, program TV dan lain-lain.

12 Arif S.Sadiman, Media Pembelajaran (Jakarta: Raja Grafindo Persada, 2002), 12. 
d. Multimedia, yaitu media yang melibatkan beberapa jenis media dan peralatan secara terintegrasi dalam suatu proses atau kegiatan pembelajaran. Pembelajaran multimedia melibatkan indera penglihatan dan pendengaran melalui media teks, visual diam, visual gerak, dan audio serta media interaktif berbasis komputer dan teknologi komunikasi dan informasi. ${ }^{13}$

Berdasarkan ragam klasifikasi media pembelajaran di atas, kita dapat memahami bahwa jenis-jenis media pembelajaran terdiri dari media visual, media audio, media audio visual dan media multimedia. Media yang digunakan dalam penelitian ini adalah media puzzle konstruksi yang berupa potongan-potongan gambar terpisah yang dapat digabungkan kembali menjadi sebuah gambar yang utuh. Media puzzle konstruksi termasuk dalam jenis media visual karena media visual sendiri adalah media yang digunakan hanya mengandalkan indera penglihatan.

Agar media pembelajaran benar-benar digunakan untuk membelajarkan siswa, maka ada sejumlah prinsip yang harus diperhatikan, di antaranya :

a. Media yang digunakan oleh guru harus sesuai dan diarahkan untuk mencapai tujuan pembelajaran

b. Media harus sesuai dengan materi pembelajaran. Setiap materi pembelajaran memiliki kekhasan dan kompleksitas

\footnotetext{
${ }^{13}$ Rayandra Asyhar, Kreatif Mengembangkan Media Pembelajaran (Jakarta: Referensi, 2012), 44-45.
} 
tersendiri. Media yang akan digunakan harus sesuai dengan kompleksitas materi pembelajaran.

c. Media pembelajaran harus sesuai dengan minat, kebutuhan, dan kondisi siswa. Setiap siswa memiliki kemampuan dan gaya belajar yang berbeda. Guru perlu memperhatikan setiap kemampuan dan perbedaan gaya belajar tersebut.

d. Media yang akan digunakan harus memperhatikan efektifitas dan efisiensi. Setiap media yang dirancang guru perlu memperhatikan efektifitas penggunaannya.

e. Media yang digunakan harus sesuai dengan kemampuan guru dalam mengoperasikannya. Media secanggih apapun tidak akan bisa menolong tanpa kemampuan teknis mengoperasikannya. Oleh karena itu, sebaiknya guru mempelajari dulu bagaimana mengoperasikan dan memanfaatkan media yang akan digunakan. ${ }^{14}$

\section{Puzzle Konstruksi}

Menurut Elib,"Kata puzzle berasal dari bahasa Inggris yang berarti teka-teki atau bongkar pasang, media puzzle merupakan media sederhana yang dimainkan dengan bongkar pasang. ${ }^{15}$ Adapun beberapa bentuk puzzle, yaitu:

a. Puzzle konstruksi

\footnotetext{
${ }^{14}$ Wina Sanjaya, Strategi Pembelajaran Berorientasi Standar Proses Pendidikan (Jakarta: Kencana Prenada Media, 2011), 173-174.

15 Elib, Landasan Teori Puzzle, dalam http://elib.unikom.ac.id/download.php?id=174148
} 
Puzzle rakitan (construction puzzle) merupakan kumpulan potongan-potongan yang terpisah, yang dapat digabungkan kembali menjadi beberapa model. Mainan rakitan yang paling umum adalah blok-blok kayu sederhana berwarna-warni. Mainan rakitan ini sesuai untuk anak yang suka bekerja dengan tangan, suka memecahkan puzzle, dan suka berimajinasi.

b. Puzzle batang (stick)

Puzzle batang merupakan permainan teka-teki matematika sederhana namun memerlukan pemikiran kritis dan penalaran yang baik untuk menyelesaikannya. Puzzle batang ada yang dimainkan dengan cara membuat bentuk sesuai yang kita inginkan ataupun menyusun gambar yang terdapat pada batang puzzle.

c. Puzzle lantai

Puzzle lantai terbuat dari bahan sponge (karet/busa) sehingga baik untuk alas bermain anak dibandingkan harus bermain di atas keramik. Puzzle lantai memiliki desain yang sangat menarik dan tersedia banyak pilihan warna yang cemerlang. Juga dapat merangsang kreativitas dan melatih kemampuan berpikir anak.Puzzle lantai sangat mudah dibersihkan dan tahan lama. Sisi edukasi permainan puzzle ini berfungsi untuk:

1) Melatih konsentrasi, ketelitian dan kesabaran. 
2) Melatih koordinasi mata dan tangan. Anak belajar mencocokkan keping-keping puzzle dan menyusunnya menjadi satu gambar.

3) Memperkuat daya ingat.

4) Mengenalkan anak pada konsep hubungan.

5) Dengan memilih gambar/bentuk, dapat melatih anak untuk berpikir matematis (menggunakan otak kiri).

6) Melatih logika anak. Misalnya puzzle bergambar manusia. Anak dilatih menyimpulkan di mana letak kepala, tangan, dan kaki sesuai logika.

7) Melatih kecerdasan anak.

8) Melatih anak agar tambah kreatif dalam berkarya. ${ }^{16}$

\section{Metode Penelitian}

Penelitian ini menggunakan jenis penelitian kuantitatif eksperimen dengan pendekatan One Grup Pretest-Posttes Design, yaitu suatu jenis penelitian yang memberikan desain pretest sebelum diberikan perlakuan yang bertujuan untuk mengetahui hasil perlakuan yang diberikan lebih akurat karena dapat membandingkan dengan keadaan sebelum dan sesudah diberi perlakuan. ${ }^{17}$

Populasi adalah keseluruhan objek penelitian Sedangkan menurut Sugiyono pengertian populasi adalah wilayah

\footnotetext{
${ }^{16}$ Rofi'ie Ariniro, Seabrek Game Perangsang Minat Baca Anak (Yogyakarta: Buku Biru, 2012), 18.

${ }^{17}$ Sugiyono, Metode Penelitian Kuantitatif, Kualitatif dan $R \& D$ (Bandung: Alfabeta, 2009), 64.
} 
generalisasi yang terdiri atas objek yang mempunyai kualitas dan karakteristik tertentu yang ditetapkan oleh peneliti untuk dipelajari dan kemudian ditarik kesimpulannya. ${ }^{18}$ Dalam penelitian ini yang menjadi populasi adalah siswa kelas V SDN Kemangsen II dengan jumlah siswa 26 orang yang terdiri dari: laki-laki 15 orang dan perempuan 11 orang.

Dalam penelitian ini, teknik pengambilan sampel dengan menggunakan teknik sampling jenuh. Sampling jenuh (total sampling) yaitu teknik penentuan sampling bila semua anggota populasi digunakan sebagai sampling. ${ }^{19}$ Peneliti menggunakan teknik sampling jenuh karena populasinya relatif kecil, yaitu kurang dari 30 orang. Jadi semua anggota populasi menjadi sampel yaitu siswa kelas $\mathrm{V}$ di SDN Kemangsen II dengan jumlah siswa 26 orang yang terdiri dari: laki-laki 15 orang dan perempuan 11 orang.

Variabel penelitian adalah segala sesuatu yang berbentuk apa saja yang ditetapkan oleh peneliti untuk dipelajari sehingga diperoleh informasi tentang hal tersebut, kemudian ditarik

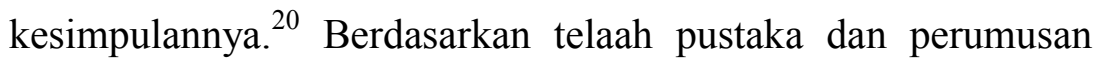
hipotesis, maka variabel-variabel dalam penelitian ini adalah:

a. Variabel Bebas (Independen)

Variabel bebas atau independen merupakan variabel yang mempengaruhi atau yang menjadi sebab perubahanya

\footnotetext{
${ }^{18}$ Sugiyono, Metode Penelitian, 80.

${ }^{19}$ Ahmad Tanzeh,Pengantar Metode Penelitian (Yogyakarta:Teras,2009), 95.

${ }^{20}$ Sugiyono, Metode Penelitian, 38.
} 
atau timbulnya variabel terikat (dependen). Dalam penelitian ini yang merupakan variabel bebas $(\mathrm{X})$ yaitu: media puzzle konstruksi.

b. Variabel terikat (dependen)

Variabel terikat (dependen) adalah variabel yang dipengaruhi atau yang menjadi akibat, karena adanya variabel bebas. Dalam penelitian ini yang menjadi variabel terikat (Y) adalah hasil belajar kognitif siswa.

Dalam penelitian kuantitatif, peneliti akan menggunakan instrumen untuk mengumpulkan data. Instrumen penelitian digunakan untuk mengukur nilai variabel yang diteliti. Dengan demikian jumlah instrumen yang akan digunakan untuk penelitian akan tergantung pada jumlah variabel yang diteliti. ${ }^{21}$ Instrumen yang digunakan dalam sebuah penelitian harusnya valid dan reliabel. Oleh karena itu peneliti memilih menggunakan instrumen penelitian yang sesuai dengan pola penelitian dan variabel yang diteliti adalah:

a. Lembar Validasi

Lembar validasi dalam penelitian ini berupa lembar validasi silabus, lembar validasi RPP, lembar validasi media puzzle konstruksi, dan lembar validasi tes hasil belajar kognitif. Lembar validasi dalam penelitian ini divalidasi oleh ahli dan digunakan untuk mengetahui apakah instrumen yang dibuat oleh peneliti tersebut dapat digunakan atau tidak.

b. Rancangan Pelaksanaan Pembelajaran (RPP)

${ }^{21}$ Sugiyono, Metode Penelitian, 92. 
RPP juga merupakan instrumen penelitian karena rancangan pelaksanaan pembelajaran (RPP) ini adalah sebuah perencanaan pembelajaran yang akan dilaksanakan oleh guru untuk dapat menerapkan media puzzle konstruksi pada mata pelajaran PKn pokok bahasan memahami kebebasan berorganisasi kelas V di SDN Kemansen II.

c. Media Puzzle Konstruksi

Media puzzle konstruksi merupakan instrumen yang akan digunakan dalam penelitian ini. Media puzzle konstruksi ini berisi gambar sesuai dengan materi pelajaran PKn pokok bahasan memahami kebebasan berorganisasi kelas V. Media puzzle konstruksi akan diterapkan setelah dilakukannya pretes.

d. Tes Hasil Belajar

Untuk mengetahui hasil belajar kognitif siswa pada kelas $\mathrm{V}$ mata pelajaran PKn pokok bahasan memahami kebebasan berorganisasi, peneliti menggunakan instrumen dalam bentuk tes. Tes ini dibagi menjadi dua tahap yaitu:

1) Pre-Tes

Pre-Tes diberikan kepada peserta didik sebelum memperoleh pembelajaran dengan menggunakan media puzzle konstruksi yang bertujuan untuk mengetahui kemampuan awal dari peserta didik dalam menyelesaikan konsep memahami pembelajaran PKn pokok bahasan memahami kebebasan berorganisasi.

2) Post-Tes 
Post-Tes diberikan kepada peserta didik setelah memperoleh pembelajaran dengan menggunakan media puzzle konstruksi yang bertujuan untuk mengetahui pengaruh penggunaan media puzzle konstruksi terhadap hasil belajar kognitif siswa dalam menyelesaikan konsep memahami pembelajaran PKn pokok bahasan memahami kebebasan berorganisasi kelas V di SDN Kemangsen II

Pengumpulan data dalam penelitian ini adalah melalui tes dan dokumentasi. Kedua metode pengumpulan data tersebut relevan dengan pendekatan dan jenis penelitian karena penelitian ini berusaha mencari ada atau tidaknya pengaruh penggunaan media pembelajaran puzzle konstruksi terhadap hasil belajar kognitif siswa.

a. Tes

Tes adalah tes yang dipergunakan untuk menilai hasilhasil pelajaran yang telah diberikan oleh guru kepada muridmuridnya, dalam jangka waktu tertentu. ${ }^{22}$

Dalam penelitian ini, metode tes ditujukan pada siswa untuk mengukur hasil belajar kognitif siswa. Pemberian tes dilakukan dua kali yaitu sebelum pemberian perlakuan (PreTes) dan sesudah pemberian perlakuan (Post-Tes). Bentuk tes yang digunakan adalah berupa tes pilihan ganda yang

22 Ngalim Purwanto,Prinsip-prinsip dan Teknik Evaluasi Pengajaran (Bandung: Rosda Karya, 2008), 147 
berjumlah 30 butir soal. Tes pilihan ganda terdiri dari $\mathrm{C} 1$ (pengetahuan), dan C2 (pemahaman).

Skala yang digunakan dalam penelitian ini yaitu skala Guttman karena skala Guttman adalah skala pengukuran dengan jawaban yang tegas, yaitu "ya-tidak", "benar-salah", dan lain-lain. Skala Guttman dapat dibuat dalam bentuk pilihan ganda. Jawaban dapat dibuat skor tertinggi satu dan terendah nol. Berikut tabel penilaian tes hasil belajar kognitif dalam penitian ini: ${ }^{23}$

Tabel 1: Penilaian tes hasil belajar kognitif.

\begin{tabular}{|l|l|c|l|}
\hline Jenis Soal & \multicolumn{1}{|c|}{ Jawaban } & Skor & Jumlah soal \\
\hline Pilihan Ganda & $\begin{array}{l}\text { Jawaban benar } \\
\text { Jawaban salah }\end{array}$ & 1 & 30 butir soal \\
& & 0 & \\
\hline \multicolumn{3}{|c|}{ Nilai yang diperoleh $=\frac{\text { Skor yang diperoleh }}{\text { skor maksimal }} \times 100$} \\
\hline
\end{tabular}

b. Metode Dokumentasi

Metode dokumentasi yaitu mengumpulkan data dengan melihat atau mencatat suatu laporan yang sudah tersedia. Metode ini dilakukan dengan melihat dokumen-dokumen resmi seperti: monografi, catatan-catatan serta buku-buku peraturan yang ada. Dokumen sebagai metode pengumpulan data adalah setiap pernyataan tertulis yang disusun oleh seseorang atau lembaga untuk keperluan pengujian suatu peristiwa atau menyajikan akunting. ${ }^{24}$

Adapun maksud digunakannya metode dokumentasi dalam penelitian ini adalah agar penulis lebih mudah

${ }^{23}$ Sugiyono, Metode Penelitian, 96.

${ }^{24}$ Tanzeh, Pengantar Metode Penelitian, 66. 
mendapatkan data, karena data telah tersedia, sehingga dapat diperoleh data dalam waktu singkat.

Metode ini digunakan untuk mendapatkan data-data mengenai latar belakang sekolah, foto-foto yang didapat peneliti selama proses kegiatan belajar mengajar tanpa menggunakan media puzzle konstruksi dan selama proses belajar mengajar dengan menggunakan media puzzle konstruksi serta dokumen-dokumen yang berkaitan dengan kebutuhan penelitian.

Metode analisis data merupakan cara untuk menganalisa hasil dari data yang diperoleh dalam penelitian. Analisis data ini dilakukan setelah terkumpulnya semua data hasil penelitian. Adapun cara yang ditempuh dalam rangka menganalisis data dalam penulisan ini dengan menggunakan metode statistik dengan hitungan komparasi. Metode analisis data yang digunakan untuk penilaian validator terhadap instrumen dengan menggunakan rating scale.

Skala pengukuran rating scale yang digunakan untuk mengukur pengetahuan, kemampuan, proses kegiatan dan lain-lain. Pengukuran ini dilakukan dengan cara memilih jawaban dengan angka pada setiap item instrumen yang terdapat pada kolom yang telah disediakan. Berikut ini pedoman penilaian dengan menggunakan skala pengukuran rating scale:

1) Kriteria skor skala penilaian adalah sebagai berikut: $5=$ Sangat baik 
Eka Wahyu Hidayati

$4=$ Baik

$3=$ Cukup baik

$2=$ Tidak baik

$1=$ Sangat tidak baik

2) Jumlah skor ideal (skor maksimal)

$\sum$ skor ideal $=5 \times \sum$ responden $\times \sum$ item angket

3) Persentase skor hasil pengumpulan data dengan rumus rating scale yaitu: ${ }^{25}$

Jumlah skor total $=\frac{\text { Jumlah skor hasil pengumpulan data yang diperoleh }}{\text { Jumlah skor ideal seluruh item }} \mathrm{X}$

4) Kriteria interpretasi presentase skor validasi

$4(75 \%-100 \%)=$ Sangat valid dan dapat digunakan tanpa revisi

$3(50 \%-75 \%)=$ Valid, dapat digunakan dengan sedikit revisi

$2(25 \%-50 \%)=$ Cukup valid dan dapat digunakan dengan revisi banyak

$1(1 \%-25 \%)=$ Sangat tidak valid dan belum dapat digunakan

\section{Hasil Penelitian dan Pembahasan}

Penelitian ini dilaksanakan di SDN Kemangsen II yang berlokasi di jalan Mayjen Bambang yuwono Kemangsen, Balongbendo-Sidoarjo. Alat instrumen yang digunakan berupa

${ }^{25}$ Sugiyono, Metodologi Penelitian, 99. 
soal tes. Instrumen tes hasil belajar ini menggunakan validasi ahli dan uji validitas.

Pengambilan data dalam penelitian ini menggunakan alat ukur berupa soal tes hasil belajar siswa jenis tes pilihan ganda. Instrumen diberikan pada sampel sebelum pemberian perlakuan (pre-test) dan sesudah pemberian perlakuan (post-test).

Tabel 2: Data Hasil Pre-test (x)

\begin{tabular}{|l|l|l|}
\hline No. & \multicolumn{1}{|c|}{ Subjek } & Pre-Test \\
\hline 1 & AWA & 40 \\
\hline 2 & AG & 33 \\
\hline 3 & ADR & 33 \\
\hline 4 & ADP & 53 \\
\hline 5 & CDL & 63 \\
\hline 6 & DDS & 53 \\
\hline 7 & DKA & 53 \\
\hline 8 & DAL & 63 \\
\hline 9 & DFP & 60 \\
\hline 10 & DWS & 47 \\
\hline 11 & FAY & 47 \\
\hline 12 & FZF & 43 \\
\hline 13 & IAR & 37 \\
\hline 14 & JSA & 57 \\
\hline 15 & KNA & 47 \\
\hline 16 & MFAF & 53 \\
\hline 17 & MAS & 50 \\
\hline 18 & NF & 60 \\
\hline 19 & RAS & 40 \\
\hline 20 & SDR & 43 \\
\hline 21 & STA & 70 \\
\hline 22 & SSS & 60 \\
\hline & & \\
\hline
\end{tabular}


Eka Wahyu Hidayati

\begin{tabular}{|l|l|l|}
\hline 23 & TWT & 63 \\
\hline 24 & WM & 57 \\
\hline 25 & MEY & 50 \\
\hline 26 & ASF & 43 \\
\hline JUMLAH & 1318 \\
\hline \multicolumn{2}{|l|}{ RATA-RATA } & 50,69 \\
\hline
\end{tabular}

Tabel pre-test adalah tabel hasil belajar siswa SDN

Kemangsen II sebelum dilakukan perlakuan menggunakan media puzzle konstruksi. Berdasarkan data hasil pre-test ternyata dapat dilihat bahwa nilai rata-rata hasil belajar kognitif siswa kelas V di SDN Kemangsen II pada mata pelajaran PKn pokok bahasan memahami kebebasan berorganisasi adalah 50,69. Hal ini, di karenakan dalam proses pembelajaran belum diterapkan media puzzle konstruksi.

\begin{tabular}{|c|c|c|}
\hline No & Subjek & Post-Tes \\
\hline 1 & AWA & 60 \\
\hline 2 & $\mathrm{AG}$ & 77 \\
\hline 3 & ADR & 77 \\
\hline 4 & ADP & 87 \\
\hline 5 & $\mathrm{CDL}$ & 83 \\
\hline 6 & DDS & 87 \\
\hline 7 & DKA & 83 \\
\hline 8 & DAL & 93 \\
\hline 9 & DFP & 90 \\
\hline 10 & DWS & 87 \\
\hline 11 & FAY & 90 \\
\hline 12 & FZF & 87 \\
\hline 13 & IAR & 77 \\
\hline
\end{tabular}




\begin{tabular}{|l|l|l|}
\hline 14 & JSA & 93 \\
\hline 15 & KNA & 83 \\
\hline 16 & MFAF & 83 \\
\hline 17 & MAS & 63 \\
\hline 18 & NF & 87 \\
\hline 19 & RAS & 77 \\
\hline 20 & SDR & 77 \\
\hline 21 & STA & 96 \\
\hline 22 & SSS & 83 \\
\hline 23 & TWT & 96 \\
\hline 24 & WM & 87 \\
\hline 25 & MEY & 90 \\
\hline 26 & ASF & 70 \\
\hline JUMLAH & 2163 \\
\hline RATA-RATA & 83,19 \\
\hline
\end{tabular}

Tabel post-test adalah tabel hasil belajar siswa SDN Kemangsen II setelah dilakukan perlakuan menggunakan media puzzle konstruksi. Berdasarkan data hasil post-test ternyata dapat dilihat bahwa nilai rata-rata hasil belajar kognitif siswa kelas $\mathrm{V}$ di SDN Kemangsen II pada mata pelajaran PKn pokok bahasan memahami kebebasan berorganisasi adalah 83,19. Hal ini dikarenakan dalam proses pembelajaran sudah diterapkan media puzzle konstruksi.

Tabel 4: Rekapitulasi Nilai Pre-test (x) dan Post-test (y)

\begin{tabular}{|l|l|l|l|}
\hline No. & \multicolumn{1}{|c|}{ Subjek } & \multicolumn{1}{|c|}{ Pre-Tes } & Post-Tes \\
\hline 1 & AWA & 40 & 60 \\
\hline 2 & AG & 33 & 77 \\
\hline 3 & ADR & 33 & 77 \\
\hline 4 & ADP & 53 & 87 \\
\hline
\end{tabular}


Eka Wahyu Hidayati

\begin{tabular}{|c|c|c|c|}
\hline 5 & CDL & 63 & 83 \\
\hline 6 & DDS & 53 & 87 \\
\hline 7 & DKA & 53 & 83 \\
\hline 8 & DAL & 63 & 93 \\
\hline 9 & DFP & 60 & 90 \\
\hline 10 & DWS & 47 & 87 \\
\hline 11 & FAY & 47 & 90 \\
\hline 12 & FZF & 43 & 87 \\
\hline 13 & IAR & 37 & 77 \\
\hline 14 & JSA & 57 & 93 \\
\hline 15 & KNA & 47 & 83 \\
\hline 16 & MFAF & 53 & 83 \\
\hline 17 & MAS & 50 & 63 \\
\hline 18 & $\mathrm{NF}$ & 60 & 87 \\
\hline 19 & RAS & 40 & 77 \\
\hline 20 & SDR & 43 & 77 \\
\hline 21 & STA & 70 & 96 \\
\hline 22 & SSS & 60 & 83 \\
\hline 23 & TWT & 63 & 96 \\
\hline 24 & WM & 57 & 87 \\
\hline 25 & MEY & 50 & 90 \\
\hline 26 & ASF & 43 & 70 \\
\hline \multicolumn{2}{|c|}{ JUMLAH } & 1318 & 2163 \\
\hline \multicolumn{2}{|c|}{ RATA_RATA } & 50,69 & 83,19 \\
\hline
\end{tabular}

Analisis Uji Normalitas dalam pengujian normalitas untuk data awal dan data akhir dengan menggunakan menggunakan rumus chi kuadrat. Berdasarkan perhitungan ditemukan harga chi kuadrat hitung $=10,04$. Harga tersebut selanjutnya dibandingkan dengan harga chi kuadrat tabel, dengan dk (derajat kebebasan) 6-1 = 5 dan taraf kesalahan 5\%, maka harga chi 
kuadrat tabel $=11,070$. Karena harga chi kuadrat hitung lebih kecil dari harga chi kuadrat tabel $(10,04<11,070)$, maka distribusi data nilai pre-test tersebut normal.

Berdasarkan perhitungan ditemukan harga chi kuadrat hitung $=10,2$. Harga tersebut selanjutnya dibandingkan dengan harga chi kuadrat tabel, dengan dk (derajat kebebasan) $6-1=5$ dan taraf kesalahan 5\%, maka harga chi kuadrat tabel $=11,070$. Karena harga chi kuadrat hitung lebih kecil dari harga chi kuadrat tabel $(10,2<11,070)$, maka distribusi data nilai post-test tersebut normal.

Setelah data berdistribusi normal, maka untuk menguji hipotesis yang telah disebutkan atau untuk mengetahui ada atau tidaknya pengaruh media bergambar terhadap hasil belajar siswa dalam pembelajaran $\mathrm{PKn}$ kelas $\mathrm{V}$ sebelum menggunakan treatment dan sesudah menggunakan treatment. Dari hasil uji hipotesis yang telah peneliti lakukan dapat disimpulkan bahwa ada pengaruh penggunaan media puzzle konstruksi terhadap hasil belajar kognitif siswa pada mata pelajaran PKn pokok bahasan memahami kebebasan berorganisasi kelas V di SDN Kemangsen II.

Besarnya pengaruh media puzzle konstruksi terhadap hasil belajar kognitif siswa. Untuk mengetahui besarnya pengaruh media puzzle konstruksi terhadap hasil belajar kognitif siswa pada mata pelajaran PKn pokok bahasan memahami kebebasan berorganisasi kelas $\mathrm{V}$ di SDN Kemangsen II, maka peneliti menggunakan uji koefisien determinasi. Berdasarkan 
perhitungan peneliti, diperoleh hasil sebesar 40,7\%. Dapat disimpulkan bahwa setelah diberikan perlakuan dengan media puzzle konstruksi dalam kegiatan pembelajaran pada mata pelajaran PKn pokok bahasan memahami kebebasan berorganisasi kelas $\mathrm{V}$ di SDN Kemangsen II, media puzzle konstruksi berpengaruh sebesar 40,7\%.

\section{Penutup}

Penelitian yang penulis lakukan tentang penggunaan media puzzle konstruksi terhadap hasil belajar kognitif siswa pada mata pelajaran PKn pokok bahasan memahami kebebasan berorganisasi kelas $\mathrm{V}$ di SDN Kemangsen II, maka dapat disimpulkan sebagai berikut:

1. Ada pengaruh penggunaan media puzzle konstruksi terhadap hasil belajar kognitif siswa pada mata pelajaran PKn pokok bahasan memahami kebebasan berorganisasi kelas V di SDN Kemangsen II terbukti nilai $\mathrm{t}$ tabel untuk kesalahan 5\% dengan $\mathrm{db}=\mathrm{N}-1=27$ adalah 2,05. Karena nilai $\mathrm{t}_{\text {hitung }}>\mathrm{t}_{\text {tabel }}$ yaitu $20,44<2,060$

2. Besarnya pengaruh media puzzle konstruksi terhadap hasil belajar kognitif siswa pada mata pelajaran PKn pokok bahasan memahami kebebasan berorganisasi kelas V di SDN Kemangsen II tahun pelajaran 2014/2015 adalah sebesar $40,7 \%$ 


\section{Daftar Rujukan}

Arikunto, Suharsimi. Dasar-Dasar Evaluasi Pendidikan. Jakarta: PT Bumi Aksara, 2013.

Ariniro, Rofi'ie. Seabrek Game Perangsang Minat Baca Anak. Yogyakarta: Buku Biru, 2012.

Arsyad, Azhar. Media Pembelajaran. Jakarta: Rajawali Pers, 2011.

Asyhar, Rayandra. Kreatif Mengembangkan Media Pembelajaran. Jakarta: Referensi, 2012.

Elib, Landasan Teori Puzzle, dalam http://elib.unikom.ac.id/download.php?id=174148

Epeni, Hani. Pengertian Media Puzzle, dalam http://kuliah.itb.ac.id/course/info.php?id=435.

Hasbullah. Dasar-dasar Ilmu Pendidikan. Jakarta: PT. Raja Grafindo Persada, 2006.

Musfiqon. Aplikasi Media Pembelajaran. Sidoarjo: Muhammadiyah University Press, 2008.

Mu'thi, Abdullah Muhammad Abdul. Be a Genius Teacher. terj. Najib Junaidi. Surabaya: Pustaka eLBA, 2008.

Purwanto, Ngalim. Prinsip-prinsip dan Teknik Evaluasi Pengajaran. Bandung: Rosda Karya, 2008.

Sadiman, Arief, S. dkk. Media Pendidikan Pengertian, Pengembangan dan Pemanfaatannya. Jakarta:Raja Grafindo Persada, 2007.

Sadiman, Arif S. Media Pembelajaran. Jakarta: Raja Grafindo Persada, 2002.

Sanjaya, Wina. Strategi Pembelajaran Berorientasi Standar Proses Pendidikan. Jakarta: Kencana Prenada Media, 2011.

Sugiyono. Metode Penelitian Kuantitatif, Kualitatif dan $R \& D$. Bandung: Alfabeta, 2009. 
Eka Wahyu Hidayati

Tim pengembang MKDP. Kurikulum \& Pembelajaran. Jakarta:Rajawali Pers, 2013.

Tanzeh, Ahmad. Pengantar Metode Penelitian. Yogyakarta: Teras,2009.

Undang-undang Republik Indonesia Nomor 20 Tahun 2003 tentang Sistem Pendidikan Nasional. Bandung: Fokus Media, 2009. 